\title{
RECOMMENDATION FOR AUTHORIZATION OVERLAPING OF PLACEMENT OF INDONESIAN FISHING VESSELS CREWS ABROAD
}

\author{
Muhammad Nur \\ Universitas Ahmad Dahlan Yogyakarta \\ email : muhammad.nur@law.uad.ac.id \\ Naskah diterima : 02/01/2018; direvisi : 26/03/2018; disetujui : 27/04/2018
}

\begin{abstract}
This normative juridical study examines the arrangement of fishing vessel crew placement from Indonesia to foreign countries which has been regulated by more than one institution. However, in the implementation of these institutions did not coordinate with each other which ultimately led to chaotic management in this sector. The fact that has been going on shows that the government is contributing to maintaining bad practices in placing and protecting the fishing vessel crew. This is based on overlapping arrangements regarding of placement and protection of fishing vessel crew. The issue that arises is related to which Ministry's rule is must be obeyed? or the executor must submit to all rules of all existing ministries? The chaos of that authority ultimately gives rise to sectoral ego of each institution that feels authoritative in this sector. This situation has implications for the protection of fishing vessel crew and the concerns of companies involved in this business sector. Through this research is expected to contribute solutions to solve the problem of chaotic management of fishing vessel crew placement abroad.
\end{abstract}

Keywords: fishing vessel crew, overlap, protection, arrangement.

\section{INTRODUCTION}

The arrangement on the placement of Indonesian fishing vessel crew abroad in general is Law No. 39 of 2004 on the Placement and Protection of Indonesian Migrant Workers Abroad. The profession as a crew of fishing vessels is included in certain occupations that require special arrangements as mandated in Article 28 of Law Number 39 of 2004. However, until now, the special arrangement order has not been implemented by the Ministry of Manpower as the carrier of the mandate. The absence of technical regulations on the placement and protection of Indonesian migrant workers abroad in seafarers sector by the Ministry of Manpower made the fate of the recruiting companies of manning agents and seafarers to be uncertain.
This is very harmful to the fishing vessel crew in terms of protection, because there are no clear rules that protect them. In addition to fishing vessel crew, the manning agents also feel the impact, one of them related licensing companies because there are some rules from several government agencies that regulate about it, including:

1. Indonesian Worker Placement License (SIPPTKI) from Ministry of Manpower according to Article 12 of the Law No. 39 of 2004.

2. Registration as Executor of Fishery Seafarers Placement (P4) at National Agency for Placement and Protection of Migrant Workers (BNP2TKI) pursuant to Regulation of Head of BNP2TKI No: PER.03 / I / KA / 2013 concerning ProceduresforPlacementandProtection 
of Migrant Workers of Fishermen in Foreign Flaged Ships.

3. Business License for Recruitment and Placement of Ships (SIUPPAK) from the Directorate General of Sea Transportation, Ministry of Transportation in accordance with Regulation of the Minister of Transportation No. PM 84 of 2013 on the Recruitment and Deployment of Ships.

In addition, the fact there are many cases of a company incorporated legal placement of fishing vessel crew. Though these companies are not in the form of Private Placement Implementers (PPTKIS) or PJTKI because the company does not have written permission in the form of SIPPTKI from the Minister of Manpower. The act of a company that places the fishing vessel crew without the written permission in the form of SIPPTKI from the Minister of Manpower is essentially a crime violating Article 102 paragraph (1) Sub-Paragraph b of Law No. 39 of 2004. However, the companies that carrying out the fishing vessel crew placement actually get permission from the Directorate General of Sea Transportation on behalf of the Minister of Transportation and placement permit from BNP2TKI.

The fact that happened during this situation that the government contributes in maintaining the persistence of bad practice in the placement and protection of fishing vessel crew abroad. This is based on overlapping arrangements related to fishing vessel crew placement and protection, namely ${ }^{1}$ :

1. There are 3 laws that have the same legal power that all three seek to regulate the issue of the fishing vessel crew both in the Act and in its derivative regulations.

1 Agustina Merdekawati dan Susilo Andi Darma, 2015, Urgensi Re-Format Tata Kelola Penempatan dan Perlindungan AKPI Yang Bekerja di Kapal Berbendera Asing dalam Rangka Peningkatan Perlindungan $\mathrm{Hu}$ kum Terhadap AKPI, Unit Penelitian dan Pengabdian Kepada Masyarakat Fakultas Hukum Universitas Gadjah Mada, Yogyakarta, Page 7.
The three laws are Law No. 13 of 2003 on Manpower, Law No. 31 of 2004 on Fisheries as amended by Law No. 45 of 2009 andLaw No.17 of2008 on Shipping. As a result, in practice, there are many overlapping and confusing rules at the implementation level. As an example of the competive management of the AKPI, each law mandates the implementing provisions of:

a. Regulation of the Minister of Transportation No. KM 9 of 2005 on EducationandTraining,Examination and Certification of Fishing Vessel Seaferers.

b. Regulation of the Minister of Marine Affairs and Fisheries Republic of Indonesia Number Per.07/Men/2011 About Quality System Standards of Education and Training, Testing, And Certification of Fishing Vessel Seaferers.

2. There are at least 5 institutions that feel the same authority to regulate the fishing vessel crew issue without any one agency that is unanimously appointed as coordinator of the fishing vessel crew issue. The five institutions are the Ministry ofMarine AffairsandFisheries, Directorate of Shipping and Marine Affairs of the Ministry of Transportation of the Republic of Indonesia, Directorate of Indonesian Citizens Protection and Legal Body of the Ministry of Foreign Affairs ofIndonesia, NationalAgency for Placement and Protection of Indonesian Workers and Ministry of Manpower. The issues that arise are related to which rules should the implementer obey? or should the implementer be subject to all rules of all existing ministries? An example is related to the requirements of a Manning Agent that can operate to send fishing vessel crew, whether it should be subject to:

a. Regulation of the Minister of Transportation No. PM. 84 of 2013 
on the Recruitment and Placement of Crew, or'

b. BNP2TKI Regulation Number: PER.12/KA/IV/2013 onProcedures for Recruitment, Placement and Protection of Seafarers on Ships of Foreign Flags.

The issue of authority related to the arrangement of fishing vessel crew placement eventually resulted in the sectoral ego of each authorized institution which has implications for the protection of the fishing vessel crew itself and the companies involved in this business sector. The focus of the issues raised in this paper are: a) How is the arrangement of placement of Indonesian fishing vessel crew abroad?; b) What is the analysis of authority theory related to the arrangement of fishing vessel crew placementabroad?; c) How is the solution related to the authorization overlaping of placement of Indonesian fishing vessels crews abroad?

\section{DISCUSSION}

\section{Arrangement of Placement of Indone- sian Fishing Vessel Crew Abroad.}

The regulation of Indonesian employment on foreign ships in general is Law No. 39 of 2004 on the Placement and Protection of Indonesian Migrant Workers Abroad. In consideration of the letters c, $\mathrm{d}$ and $\mathrm{e}$, it is mentioned that Indonesian labor abroad is often used as the object of human trafficking, including slavery and forced labor, victims of violence, arbitrariness, crimes against human dignity and other violations of human rights. Therefore, the state shall guarantee and protect the human rights of its citizens working both at home and abroad based on the principle of equal rights, democracy, social justice, equality and gender justice, anti-discrimination and anti trafficking. In the case of Indonesian employment abroad is an attempt to create equal rights and opportunities for the workforce to obtain decent employment and income, whose implementation is carried out with due regard to the dignity, human rights and legal protection as well as equal employment opportunities and the provision of manpower in accordance with national needs.

Seafarers' profession belongs to certain occupations or positions that require special arrangements as mandated in Article 28 of Law No. 39 of 2004. The protection aspect of Indonesian employment on foreign fishing vessels is closely linked to the management and regulatory system by various parties involved in sending Indonesian workers aboard foreign fishing vessels. However, since the mandate of Article 28 of Law Number 39 of 2004 has not been implemented, some government agencies have finally initiated to issue some related rules to regulate the fishing vessel's crew. The institutions involved in managing the placement of fishermen are: a. Ministry of Manpower of the Republic of Indonesia

Regarding the placement management of fishing vessel crew, the Ministry of Manpower regulates several issues, including issuing Permit for Placement of Indonesian Workers (SIPPTKI). The Placement License for Placement of Indonesian Migrant Workers hereinafter referred to as SIPPTKI is written permission granted by the Minister to the private company which will be the implementer of the placement of Indonesia workers (Article 1 (13) Law No. 39 of 2004 on Placement and Protection of Indonesian Workers). In order to obtain the SIPPTKI, that private company must comply with the requirements regarding to Article 13 (1) Number 39 of 2004 on Placement and Protection of Indonesian Workers, there are: 
1) in the form of a limited liability company (PT) established under the laws and regulations;

2) having paid up capital as stated in the deed of establishment of the company, atleast of Rp.3,000,000,000.00 (three billion rupiah);

3) depositing money to the bank as collateral in the form of deposits of Rp. 15,000,000.00 (fifteen million rupiah) at a government bank;

4) having a work plan for the placement and protection of Indonesia workers abroad for at least 3 (three) years;

5) have a job training unit; and

6) have facilities and infrastructure of placement service for Indonesian workers.

To carry out its role as an company of placement of migrants workers in the form of labor recruitment, in Article 32 (1) of Law Number 39 of 2004 on Placement and Protection of Indonesian Workers stipulates that private company who will undertake recruitment shall have SIP ( License of Deployment) from the Minister. Then, in Article 32 (4) it is explained that the procedures for issuing SIP shall be further stipulated by a Ministerial Regulation. Based on this mandate, the Ministry of Manpower subsequently issued the Regulation of the Minister of Manpower of the Republic of Indonesia No. 22 of 2014 on the Implementation of the Placement and Protection of Indonesian Migrant Workers Abroad. In Article 2 (2) of this Ministerial Regulation stipulates that with regard to technical SIP, the Minister shall appoint the Head of BNP2TKI to issue the SIP.

b. National Agency for Placement and Protection of Indonesian Workers (BNP2TKI)

The National Agency for the Placement and Protection of Indonesian Migrant Workers is a non-ministerial government agency responsible to the President (Article 94 (3) of Law Number 39 of 2004 on the Placement and Protection of Indonesian Migrant Workers). As mentioned earlier, in accordance with the mandate of Article 2 (2) of Regulation of the Minister of Manpower of the Republic of Indonesia Number 22 of 2014 on the Implementation of the Placement and Protection of Indonesian Migrant Workers abroad states that related to SIP technical, The Minister appointed the Head of BNP2TKI to issue the SIP. Article 32 (2) of Law Number 39 of 2004 concerning thePlacementandProtection of Indonesian Workers jo. Article 3 (1) Regulation of the Minister of Manpower of the Republic of Indonesia Number 22 of 2014 provides that in order to obtain SIP, PPTKIS must submit a written application to the Head of BNP2TKI by enclosing the document:

1) copy of placement cooperation agreement;

2) letter of request from migrant user/ job order/demand letter/wakalah;

3) draft of agreement; and

4) draft of placement agreement.

The period of validity of the SIP is in accordance with the letter of request of the Indonesian migran workers from the user with the provision not to exceed 6 (six) months, and can be extended 1 (one) time for a maximum period of 3 (three) months with the provisions of the period of requestletter of the migrant worker (Article 7 (2) and (3) Regulation of the Minister of Manpower of the Republic of Indonesia No. 22 of 2014 on the Implementation of the Placement and Protection of Indonesian Migrant Workers Abroad).

c. Ministry of Marine Affairs and Fisheries of the Republic of Indonesia

Regulation of the Minister of Marine Affairs and Fisheries No. 35/PERMENKP/2015 on Human Rights System and Certification in Fishery Enterprises 
is a policy issued by the Minister of Marine Affairs and Fisheries because of the existence of various human rights violations, such as cases of trafficking, forced labor, child labor, and workplace conditionsthatarenotinaccordancewith laws and regulations relating to human rights and employment. This is what makes the Ministry of Marine Affairs and FisheriesfinallyissuedaRegulationofthe Minister on Fisheries Rights, so that the future fate of Indonesian workers in the fishery sector can be further protected.

Article 6 Paragraph (3) SubParagraph $b$ and Sub-Paragraph $c$ of the Minister of Marine Affairs and Fisheries concerning the recruitment system of the workers and crew of the fishing vessel shall include procedures to ensure the recruitment of workers and crew of fishing vessels, the fulfillment of minimum competency requirements and age for workers and fishermen; application of employment agreements and marine working agreements and on the employment system which includes the fulfillment of the terms of collective labor agreements or company regulations, the fulfillment of health insurance and workplace injury for workers, and the fulfillment of social security requirements.

In addition, in the Annex to the Ministerial Regulation also states that a fishery company must have SOP on the recruitment of fishing crew and workers who stipulate that:

1) Recruitment of fishing vessel crews shall be carried out by authorized institutions which allowed as fishing service agencies that has licensed by the Ministry of Manpower;

2) Recruitment costs are not charged by the fishermen and/or workers;

3) Employment agreements for fishing vessel crew and/or worker should be made in a fair, transparent, nondiscrimination and in a format and language that is easy to understand and must be signed by all parties;

4) Fishing vessel crew shall not use outsourcing labor;

5) All fishing vessel crew and/or worker may become a member of legitimate and recognized labor union;

6) Document of marine working agreement kept by fishery businessman and held by each fishing vessel crew and/or worker; and

7) the fishing vessel crew agency should be officially registered at the marine and fisheriesministry as afisherycrew supplier.

d. Ministry of Transportation Republic of Indonesia

Education and training for seafarers' fishing vessels is crucial in improving the human resource capacity of crew and prospective crew. Thus, in 2005 the Ministry of Transportation issued Minister of Transportation Regulation No.KM9 of2005 onEducation, Training, Testing and Certification of Fisheries Seafarers.Thebasisfortheissuanceofthis rule is Government Regulation Number 7 of 2000 on Marine. In the Ministry of Transportation Regulation KM 9 of 2005 Article 2 paragraph (3) states that the education and training of seafarers fishing vessel held by the Minister that has responsible in the field of fisheries, in this case is the Minister of Maritime Affairs and Fisheries after getting a recommendation from the Minister of Transportation.

The education and training of seafarer fishing vessels shall be carried out by education units and/or fisheries training or educational legal entities based on the quality standard system in accordance with applicable laws and regulations. Provisions concerning quality standard system of education and training, test and seafarers certification shall be further regulated by a Ministerial Regulation that has responsible in 
fisheries. Education and training of seafarers are classified as:

1) Professional Education and Training ofFishing Vessels Seafarers, is aformal education of secondary and higher education to obtain Certificate of Fishing Vessel Seafarers;

2) Functional Education and Training of Seafarer of Fishing Vessels, is a non-formal education of increasing the profession level of fishing vessels seafarers;

3) Education and Training of Seafarer Fishing Vessels Skill is non-formal education skills to perform specific jobs on fishing vessels.

In addition, the Ministry of Transportation also issued regulations related to the recruitment and placement of crew. This provision is set forth in the Minister of Transportation Regulation No. 84 of 2013 signed by EE Mangindaan on October 4, 2013 and enacted in the state news by the Minister of Law and Human Rights on October 7, 2013. This Minister of Transportation Regulation is a derivative regulation of Law No.17 of 2008 on Shipping then described in Government Regulation No. 20 of 2010 on Water Transportation. One of the articles in the Government Regulation states that the provisions concerning the recruitment and placement of crew are regulated in ministerial regulations.

In principle, this provision governs the procedures and licensing procedures of the ship's agency business, the recruitment and placement of seafarers on board and the required documents, including the arrangement of the return of the crew. In addition, the Minister of Transportation Regulation also contains sanctions for companies that violate and regulate seafarers' disputes. Agent companies shall settle disputes arising between seafarers and ship owners/ operators, or seafarers with agency companies, either through deliberation
orlegallyundertheSea WorkAgreement. If it can not be resolved, the parties may resolve through an industrial relations court based on the Sea Work Agreement and other supporting documents. While the vessel agent business licenses are issued by the Directorate General of Sea Transportation on behalf of the Minister of Transportation, in the form of License for Recruitment and Ship Operation (SIUPPAK).Thispermitisvalidaslongas thereisnorevocationfromtheDirectorate General of Sea Transportation.

\section{Analysis of Authority Theory Regard- ing Arrangement of Fishing Vessels Crew Placement Abroad}

To examine the role of each institution involved in managing the fishing vessel crews abroad, there are various problems that arise. One of them is related to the authority as a regulator, there is an overlap of authority among the institutions. The status, functions and duties of BNP2TKI have been regulated in Article 95 paragraph (1) of Law No. 39 of 2004 on Placement and Protection of Indonesian Migrant Workers Abroad and Article 3 of Presidential Regulation no. 81 of 2006 on BNP2TKI which basically provides that BNP2TKI acts as operator on policies issued by the Ministry of Manpower as regulator. However, on the grounds that since the Law No. 39 of 2004 on Placement and Protection of Indonesian Migrant Workers Abroad has been passed, until now there has not been a technical regulation which is the authority of the Ministry of Manpower and Transmigration as regulator to issue it as mandated in Article 28 of the Law No. 39 of 2004 on Placement and Protection of Indonesian Migrant Workers Abroad which resulted in many deadlocks of cases settled by fishing vessles vrews, ultimately encouraging BNP2TKI to issue its own rules for Indonesia fishing vessles vrews on the grounds of the legal vacuum. One 
of them is Head of BNP2TKI Regulation no. 12 of 2013 on the Procedures for the Placement and Protection of Indonesian Fishermen Seafarers in Foreign Flaged Ships.

As the concept of public law, authority (bevoegdheid) is described as the rule of law (rechsmacht), in which the concept is related in the formation of besluit (governmental decree) which must be based on an authority ${ }^{2}$. In other words, the government's decision by the competent organs should be based on clearly defined authority, whereby the authority has already been established in the rule of law that first exists. ${ }^{3}$ In line with the above opinion, F.P.C.L. Tonnaer ${ }^{4}$, states that:

"Overheidsbevoegdheid wordt in dit verband opgevat als het vermogen om positiefrecht vast te stellen $n$ aldus rechtsbetrekking tussen burgers onderling en tussen overheid en te scheppen"( (The authority of the government in this regard is regarded as the ability to enforce the positive law, and thereby the detailed legal relationship between the government and the citizens)."

Later, Philipus M. Hadjon ${ }^{5}$ also points out that:

"... at least the basic authority must be found in a law, if the ruler wants to put the obligations above the citizens. Thus there is in it a democratic legitimacy. Through legislation, parliament as a legislator representing the people of its constituencies also determines what obligations are appropriate for the citizens. From this point, the attribution and delegation of authority must be based on formal laws, at least when the decision places obliga-

2 Philipus M. Hadjon, 1997, Tentang Wewenang, Makalah, Universitas Airlangga, Surabaya, Page 5.

3 Sutarman, 2007, Kerjasana Antar Daerah Dalam Pelayanan Perizinan dan Penegakan Hukum Penangkapan Ikan Di Wilayah Laut, Disertasi, Program Pascasarjana Universitas Airlangga, Surabaya, Page 110.

4 Ridwan HR, 2002, Hukum Administrasi Negara, Raja Grafindo Persada, Jakarta, Page 101.

$5 \quad$ Philipus M. Hadjon, Op.Cit., Page 130. tions on the community "

The study in administrative law, emphasizes the importance of knowing the source and the way of obtaining the authority of government organs, since it relates to legal accountability (rechtelijke verantwording) in the use of such authority, in accordance with one of the principles of the rule of law; "Geen bevoegheid zonder verantwoordelijkheid or there is no authority without responsibility". 6

The source of authority can be seen in the constitution of each country which gives a legitimacy to the public bodies to perform its functions. ${ }^{7}$ In carrying out its functions especially those relating to the authority of government, the Government obtains such power or authority derived from the constitution. Sutarman quotes from H.D. van Wijk/Willem Konijnenbelt, who stated that ${ }^{8}$ :

"Wetmatigheid van bestuur: de uitvoerende mach bezit uitsluitend die bevoegdheden welke haar uitdrukkelijk door de grondwet of door een andere wet zijn toegekend". (Government by law: the government obtains the powers granted to it by law or constitution).

In relation to governance, the government has a helper structure that is formed based on its needs. The legal basis for the establishment of the Ministry is in Chapter V Article 17 of the 1945 Constitution which explains that: (1) The President is assisted by state ministers. (2) The Ministers shall be appointed and dismissed by the President. (3) Every minister in charge of certain affairs in government. (4) The establishment, alteration, and dissolution of state ministries shall be governed by law. In addition, the ministry is also regulated by Law No. 39 of 2008 on State Ministries

6 Ridwan HR, Op.CIt., Page 108.

$7 \quad$ Tatiek Sri Djatmiati, 2004, Prinsip Izin Usaha Industri di Indonesia, Disertasi, Program Pascasarjana Universitas Airlangga, Surabaya, Page 60.

8 Sutarman, Op.Cit., Page 112. 
and Presidential Regulation No. 7 of 2015 on the Organization of State Ministries. In addition, there are also non-ministerial government agencies established to perform certain government duties of the president.

Ministry of Manpower and BNP2TKI is a government agency that takes care of all matters relating to Indonesia workers abroad. The similarity of functions between the two institutions makes their policies often intersect and lead to dualism of regulation and service. In the consideration of letter a of Presidential Regulation No. 81 of 2006 on BNP2TKI mention:

"That in order to realize the objective of placement and protection of Indonesian workers abroad as referred to in Law Number 39 of 2004 concerning the Placement and Protection of Indonesian Workers Abroad, it is necessary to establish a National Agency for the Placement and Protection of Indonesian Migrant Workers as a government institution for implement policies in the field of placement and protection of Indonesian workers in a coordinated and integrated manner."

While in Article 1 of Presidential Regulation No. 81 of 2006 states:

"The National Agency for Placement and Protection of Indonesian Workers, hereinafter referred to as BNP2TKI, is a nondepartmental government institution under and responsible to the President"

In the Consideration letter a of Presidential Regulation No. 81 of 2006 above formulates that BNP2TKI is the implementing body of policy, and in Article 1 of the Presidential Regulation, BNP2TKI has direct responsibility to the President. However, if we examine Article 17 of the Constitution, paragraph 1 states that "the President is assisted by ministers of state" and in paragraph 3 explained that "every minister in charge of certain affairs in government". In this case, the Ministry of Manpower is led by a minister who has the authority to formulate and make national policies, implementation policies, and labor technical policies.

Observing the rules above, showing equality between the BNP2TKI and the Ministry of Manpower, which is directly responsible to the President. But BNP2TKI is the implementing agency of policy while the Ministry of Manpower as the formulator and policy maker. This creates inconsistencies in the rule of law because government agencies should implement policy and policy makers should not be aligned. The provisions are regulated in Article 25 paragraph 2 of Law No. 39 of 2008 on State Ministries. In addition, according to Jimly Asshiddiqie, the ranking of state institutions depends, of course, on the degree of regulation by law. The state institutions regulated and constituted by the Constitution are constitutional organs, whereas those established by law are the organs of the law, while those formed only by the President's decision are lesser degree and the degree of legal treatment of the officials who sit there. ${ }^{9}$

In the theory of authority it is known that the granting of authority is based on attribution, delegation, or mandate attached to officials to make decisions or take action in government or public affairs. Philipus M. Hadjon argues that any decision and/or action of officials must be based on legitimate authority, either by attribution, delegation, or mandate (the theory of authority has been accommodated in Article 8 Paragraph (1) of the Government Administration Law). The dispute due to the lack of clarity of authority between the ministries above is basically due to the authority given in one related governmental area, but there is no clear division of authority and the proportion of each institution that can support the achievement of goals related

9 Jimly Asshiddiqie, 2010, Hukum Acara Pengujian Undang-Undang, Sinar Grafika, Jakarta, Page 60-61. 
to the placement of fishing vessel crew abroad.

The Government Administration Act was established to arrange the dispute resolution of authority by using the principle of "coordination to produce agreement". The arrangements are contained in Article 16 of the Government Administration Law. However, the provision of coordination to produce the agreement is actually just an obscura provision that does not clarify how technical dispute resolution authority. The lack of clarity in the pattern of relations between state institutions has led to further implications of potential authority disputes among state institutions. ${ }^{10}$ When looking at the example of overlapping disputes over the placement authority of fishing vessels crew abroad, the coordination has been done between related institutions but the agreement is not easy to achieve. The follow up and how the role of the President in deciding the dispute of authority within the government is also not clearly regulated in technical implementation. Whereas the role of the President in the settlement of the dispute is very great as it has done in 2012 when there is a dispute over authority between the Corruption Eradication Commission (KPK) with the Police Agency related to the case of procurement of simulation tools for driving two-wheeled and fourwheeled vehicles for driving license test. At that time President Susilo Bambang Yudhoyono took a firm stand in resolving the dispute between the Corruption Eradication Commission and the Police Agency by setting four policies.

Therefore, it is necessary to elaborate the technical provisions to implement the dispute over the authority of the Government Administration Act. Current ways and alternatives to dispute resolution

10 Zainal Arifin Mochtar, 2016, Lembaga Negara Independen: Dinamika Perkembangan dan Urgensi Penataannya Kembali Pasca-Amandemen Konstitusi, Rajawali Pers, Jakarta, Page 141. are generally well known, from negotiation, mediation, or litigation. In the case of authority disputes related to state finances, state assets, and/or the environment, the settlement of disputes has been clearly established under the State Finance Law, the Anti-Corruption Eradication Act, and the Environmental Law. However, beyond that, the way and alternative dispute resolution of authority is not yet clearly regulated in the Government Administration Law. That is, in the Law on Administration of Government open discretionary opportunities in terms of dispute resolution of authority.

\section{Solutions Related to the Management of Indonesian Fishing Vessel Crews Abroad}

Based on the results of dispute analysis of authority related to the arrangement of aboard fishing crew abroad placement above, the author tries to provide solutions in the hope can be an idea to solve the problem. The author's solution is made in " 3 in 1 Collaboration" system. This recommendation focuses on the collaboration among the three ministries that most often intersect in terms of placement managing the fishing vessels crews abroad namely the Ministry of Manpower, the Ministry of Transportation and the Ministry of Marine Affairs and Fisheries and also added BN2TKI as executor in accordance with the purpose and function of its formation.

The collaboration between the three ministries that the writers try to initiate must begin in good faith among the three ministries for serious negotiations. The goodwill can also be initiated by the President of the Republic of Indonesia to bring together the three ministries and BNP2TKI to conduct negotiations related to their respective authorities. If you look at the progress so far, among the ministries in fact has been several times to talk about the fishing vessel crews authority, 
but no concrete results have changed the pattern that goes so far. In the absence of the results set forth in the collective agreement resulted in the outcome of the talks being unenforceable and tending only to formality.

The discussion that must be done is how to divide the roles and authority of each ministry in placement arrangement of fishing vessels crew abroad. As it has been so far, the case of arranging the placement of Indonesian migrant workers abroad although closely related to labor regulation but can not be managed by the ministry of labor only because the profession as AKPI is a special profession that requires special arrangement (lex specialis) and expertise related to other ministries. For example, the regulations regarding the necessity of each fishing vessel crew (Basic Safety Training for all Fishing Vessel/BST-F Certificate) that obtained through BST-F education and training.

The education and training of fishing vessels seafarer shall be carried out by education units and/or fisheries training or educational legal entities based on the quality standard system in accordance with applicable laws and regulations. The provisions concerning the system of quality standards of education and training, examination and certification of fishing vessel seafarers shall be further regulated by a Ministerial Regulation responsible for fisheries after obtaining a recommendation from the Minister of Transportation (See Article 2 paragraph (3) Ministry of Transportation Regulation KM. 9 of 2005 on Education, Training, Testing and Certification of Seafarers). However, so far the Ministry of Manpower has also regulated the education and training of BST-F while the Ministry of Manpower itself has no authority to carry out such training and certification, but only grants its implementation permits to third parties. So naturally the two previous ministries should took over these responsibilities because already have management related to it.

Another example is related to the authority to issue business permits for the placement of fishing vessels crew abroad by private parties (PPTKIS) which has been reaping dualism of arrangements in the Ministry of Manpower and the Ministry of Transportation. It should be understood that most of the PPTKIS are overseas labor placement companies that mobilize migrant workers in various job sectors. Therefore, since this is a labor placement company that not only employs fishing vessels crew but is a general migrant labor company in various job sectors, it is naturally regulated by the Ministry of Manpower as a ministry that generally regulates domestic and overseas employment. The authors are more likely to agree if they amend the provisions of the License of Recruitment and Placement of Ships Crew (SIUPPAK) from the Directorate General of Sea Transportation, Ministry of Transportation in Regulation of the Minister of Transportation. PM 84 of 2013 on the Recruitment and Placement of the Ships Crew shall be a Recommendations of Business Recruitment and Placement of Ships Crew. The recommendation function is a special additional requirement only for PPTKIS which also wishes to carry out business in recruitment and placement of fishing vessels crew overseas.

As a result of the negotiations between the ministries, the authors recommend outlined in the form of a Joint Decree (SKB) of Three Ministers. Thus, there are concrete forms that can be generated and implemented by concerned parties. The result of this decision shall be the duty of BNP2TKI in accordance with its objectives and functions in Article 95 (1) of Law Number 39 of 2004 concerning the Placement and Protection of Indonesian Migrant Workers as a policy implementation in the field of 
placement and protection of Indonesian workers abroad in a coordinated manner and integrated (see Article 95 (1) of Law Number 39 of 2004 on the Placement and Protection of Indonesian Migrant Workers). Thus, BNP2TKI should not and no longer need to issue its own rules, because its function is only at the level of implementing the policy.

The author also encourages the establishment of One Stop Integrated Service with "Single Submission" system for licensing services. This service is carried out by BNP2TKI as a licensing and non-licensing policy implementer, whose management process starts from the stage of application until the publication of a document conducted in one place. During this time, the complaints from parties related to the placement of fishing vessels crew abroad is the length and complexity of the bureaucracy that must be passed, so that with One Stop Integrated Service is expected to make it easier and cut the time and expenses that must be incurred by related parties. This service is also expected to strengthen coordination among ministries so that if there are problems in the field can be overcome quickly. The flow of these recommendations can be seen simply below.

Recommended Flow Chart Management for Placement of Fishing Vessels Crew Abroad

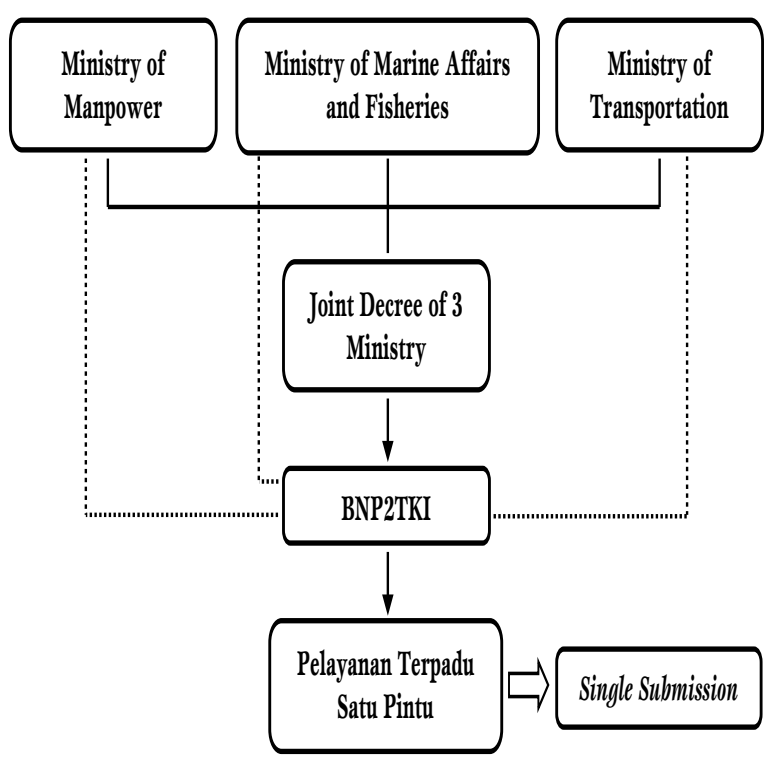

The recommendations are not easy to implement immediately. It takes serious and mature planning to create effective rules and services in the management of the placement of these fishing vessels crew. However, there must be concrete steps to stop the chaos in the arrangement. The assertiveness and initiation of the President as the head of the government that oversees all these institutions is also needed in order to suppress the ego of each institution. Hopefully with this recommendation, various issues related to the management of placement of fishing vessels crew can be minimized so as to ensure the safety protection of fishing vessels crew abroad.

\section{CONCLUSION}

Based on the description of the problem formulation above, it can be concluded that: 1) The arrangement of placement of Indonesian fishing vessels crews that working on foreign vessels is closely related to the management system and arrangements made by various parties involved in sending Indonesian workers to foreign fishing vessels aboard. However, since the mandate of Article 28 of Law Number 39 of 2004 has not been implemented, some government agencies have finally initiated to issue some relevant rules to regulate the placement of fishing vessel crews that are indeed related to the authority given by the legislation. The institutions involved in governance arrangements for the placement of fisheries crew, among others: Ministry of Manpower, Ministry of Transportation, Ministry of Marine Affairs and Fisheries and BNP2TKI. 2) Analysis of authority theory related to the arrangement of fishing vessel crew placement abroad is using Attribution Authority, Delegation Authority and Mandate Authority. The results of the authors' study found that each of the disputing institutions based on the authority theory has the authority 
given by attribution to act in one area of governmental affairs, but there is no clear division of authority in the field, where the division of authority is not based on the proportion which can supports the attainment of the goal of fishing vessel crew placement abroad. Thus, it takes a serious settlement of disputes related to the authority through some alternative dispute resolution and the establishment of more technical and operational regulations. 3) Recommendations related to the governance of fishing vessel crews placement abroad through the " 3 in 1 Collaboration" system through One Stop Integrated Service with "Single Submission" system for licensing service, which focuses on collaboration between Ministry of Manpower, Ministry of Transportation and Ministry of Marine Affairs and Fisheries plus BNP2TKI as policy implementers.

The writer's suggestion related to the sustainability of governance of Indonesian fishing vessels crews in various countries, namely: 1) Harmonization of institutions is necessary to avoid the ego of institutions that have a negative impact on governance placement of Indonesian fishing vessels crews abroad. 2) The government should be more oriented towards protection Indonesian fishing vessels crews not only see the solving side of unemployment problem in Indonesia. The orientation can be done through revamping the integration of related ministries by forming a task force that will guard the process of licensing from beginning to end. 3) Involvement of non-governmental parties in the policy of governance management of placement of Indonesian fishing vessels crews abroad.

\section{BIBLIOGRAPHY}

\section{Books}

Amiruddin dan Zainal Asikin. 2004. Pengantar Metode Penelitian Hukum. PT Raja Grafindo Persada. Jakarta.
Jimly Asshiddiqie. 2010. Hukum Acara Pengujian Undang-Undang. Sinar Grafika. Jakarta.

Ridwan HR. 2002. Hukum Administrasi Negara. Raja Grafindo Persada. Jakarta

Zainal Arifin Mochtar. 2016. Lembaga Negara Independen: Dinamika Perkembangan dan Urgensi Penataan Kembali PascaAmandemen Konstitusi. Rajawali Pers. Jakarta.

\section{Others}

Agustina Merdekawati dan Susilo Andi Darma. 2015. Urgensi Re-Format Tata Kelola Penempatan dan Perlindungan AKPI yang Bekerja di Kapal Berbendera Asing dalam Rangka Peningkatan Perlindungan Hukum Terhadap AKPI. Unit Penelitian dan Pengabdian Kepada Masyarakat Fakultas Hukum Universitas Gadjah Mada, Yogyakarta.

Philipus M. Hadjon. 1997. Tentang Wewenang. Makalah. Universitas Airlangga. Surabaya.

Sutarman. 2007. Kerjasana Antar Daerah dalam Pelayanan Perizinan dan Penegakan Hukum Penangkapan Ikan di Wilayah Laut. Dissertation. Graduate Program Universitas Airlangga. Surabaya.

Tatiek Sri Djatmiati. 2004. Prinsip Izin Usaha Industri di Indonesia. Dissertation. Graduate Program Universitas Airlangga. Surabaya.

Tim Bahasa Pustaka. 1996. Kamus Besar Bahasa Indonesia. Balai Pustaka. Jakarta.

\section{Regulations}

Law No. 39 of 2004 concerning the Placement and Protection of Indonesian Workers Abroad 
Muhammad Nur|Recommendation For Authorization Overlaping Of Placement Of Indonesian Fishing.......

published in the State Sheets of 2004 No. 133 and Supplementary State Sheets of the Republic of Indonesia No. 4445.

Law Number 30 of 2014 on Government Administration published in the State Sheets of 2014 No. 292 and Supplementary State Sheets No. 5601.

Government Regulation Number 7 of 2000 on Marine published in the Supplementary State Sheets of the Republic of Indonesia No. 3929.

Presidential Regulation No. 18 of 2015 on the Ministry of Manpower is published in the State Sheets of the Republic of Indonesia of 2015 Number 19.

Decree of the Minister of Transportation Number 46 of 1996 on the Certification of Seaworthy of Fishing Vessels.

Decree of the Minister of Marine Affairs and Fisheries Number 21 of 2004 on the Design and Equipment Requirements of Fishing Vessels.

Regulation of the Minister of Transportation KM. 9 Year 2005 on Education and Training of Examination and Certification for Fishing Vessel Sailors.

Regulation of the Minister of Maritime Affairs and Fisheries Number 07 of 2010 on the Letter of Worthy of Fishery Vessel Operations.

Regulation of the Minister of Manpower of the Republic of Indonesia Number 22 of 2014 on the Implementation of the Placement and Protection of Indonesian Migrant Workers Abroad.

Head of BNP2TKI Regulation Number 12 of 2013 on Procedures for Recruitment, Placement and
Protection of Seafarers on Ships of Foreign Flags. 